\title{
Humans, Nature and God: Exploring Images of Their Interrelationships in Victoria, Canada*
}

\author{
Mirjam de Groot ${ }^{*_{a}}$ and Riyan J.G. van den Born ${ }^{\mathrm{b}}$ \\ a Centre for Sustainable Management of Resources, Faculty of Science, Mathematics and \\ Computing Science, Radboud University Nijmegen, The Netherlands; ${ }^{\mathrm{b}}$ Department of \\ Philosophy and Science studies, Faculty of Science, Mathematics and Computing Science, \\ Radboud University Nijmegen, The Netherlands \\ M.deGroot@science.ru.nl
}

\begin{abstract}
This study explores visions of nature among five populations in Victoria, a small city in British Columbia, Canada: Christians, Muslims, Native Americans, Buddhists, and secularists. Each group was asked to express their view of the human relationships with nature based upon four approaches: mastery over nature, stewardship in regard to the creation, a partner, or a participant in the processes of nature. The first model, in which humans wield hierarchical power and mastery over nature, was rejected by all groups. Christians and Muslims adhered to the stewardship image of the human/nature relationship, while Buddhists and Native Americans considered themselves to be participants in nature. The secularists made combinations of the approaches to exemplify their view. Twenty-seven individuals participated in extensive interviews as part of this study, which also included a small scale written survey of fifty-three persons.
\end{abstract}

\section{Keywords}

visions of nature, values of nature, attitudes toward nature, religion, environmental ethics

\footnotetext{
*) We wish to thank the Coastal Inquiries project and the Centre for Studies in Religion and Society at the University of Victoria for offering the fellowship that enabled us to carry out this research in Canada. We would also like to thank Hub Zwart, Wim Hofstee and Wouter de Groot for their enthusiasm for this project and their valuable comments.
} 


\section{Introduction}

In 1967, Lynn White, Jr., asserted that Christian attitudes toward nature have caused an ecological crisis. Since that time, various theologians and philosophers have criticized the despotic actions taken by human beings toward nature and the role of Christianity in shaping an overbearing and harmful anthropocentrism. Barbour (1974) and Passmore (1980) have lamented the domination of humans over nature; both regard the Jewish and Christian traditions to be the cause of extensive abuse. Two assumptions can be distinguished in this debate: "Western culture is one of mastery over nature" and "Christianity is the basis for this domineering attitude". Most theologians today recognize that not only Christianity but religions in general "are key shapers of people's world-views and formatters of their most cherished values" (Tucker and Grim 2001). This recognition broadens the debate from White's analysis of Christian morality to the effect that any religion or worldview might have on attitudes towards nature.

Whereas the philosophical and theological literature on attitudes towards nature has expanded massively due to the debate, the empirical foundation does not provide satisfactory answers to accept or reject the hypotheses stated above. Starting with the first hypothesis, on mastery over nature, empirical studies tend to focus primarily on the images of human/nature relationships among special groups like farmers (Kaltoft 1999), women (Modelmog 1998) or children (Kahn 1999; Nevers 1997). Examples of broader studies are Kellert's (1989) quantitative research on attitudes towards animals in American culture, the study by Buijs and Filius (1998) on images of nature in the Netherlands and studies applying the New Environmental Paradigm (NEP) Scale of Dunlap et al. (2000). This widely used scale consists of 15 items to measure an environmental worldview. ${ }^{1}$

The research group Social Environmental Sciences, Nijmegen, has developed a general instrument to measure the image that people have of the human/nature relationship, the Human and Nature (HaN) scale. The multidimensional HaN-scale can measure ecocentric attitudes like the "Partner" and the "Participant in Nature", whereas the NEP-scale can only express a certain degree of anthropocentrism. This is a serious limitation,

1) Notice that beside the social scientific research as mentioned, a new direction towards more empirical studies is emerging within philosophy. See, for instance, http://www.xs4all. $\mathrm{nl} /$ - ozse/research_eng.htm. 
considering, for instance, that Buijs and Filius (1998) have shown that $92 \%$ of the Dutch respondents acknowledge that nature has intrinsic value. In Norway and Sweden, ${ }^{2}$ these figures are $83 \%$ and $78 \%$ respectively. The tendency of the Dutch population to opt for a more or less eco-centric human/nature relationship also has become clear in recent studies of van den Born et al. (2001), de Groot and van den Born (2003), and van den Born (2006), which reveal that most of the respondents see themselves as a "Steward of Nature" (endorsing the idea that they are responsible for nature) or as Participants in nature (seeing themselves as belonging to nature). These results challenge the generally accepted image of masters over nature, which tends to dominate the philosophical debate triggered by Lynn White and others.

The present study broadens the perspective of the $\mathrm{HaN}$-scale research in that it also includes religion as a possible shaper of the human/nature relationship. Most empirical studies on religion and the environment focused on Christianity in relation to environmental concern. Some had a marginal representation of environmental concern with only a few items, mostly on the amount of money that should be spent on environmental issues (Greeley 1993; Guth et al. 1995; Boyd 1999). Others broadened the concept of environmental concern by the inclusion of items on mastery over nature (Hand and Van Liere 1984; Shaiko 1987; Woodrum and Hoban 1994), which makes these studies more in line with White's hypothesis. Yet, like Shaiko (1987) states, it seems inadequate to study masteryover-nature as the only human-nature relationship among religious individuals. He suggests that the biblical image of Stewardship should get more attention. Eckberg and Blocker (1996) attempted this, but their items, on animal rights and sacred nature, did not give a full representation of a Steward. ${ }^{3}$ The most extended elicitation of the human/nature relation-

2) Grendstad and Wollebaek (1998) found that of a sample of $\mathrm{n}=965$ from the general public in Norway, $83 \%$ agreed strongly or mildly that "all ecosystems, however small and insignificant, have a right to exist", while $76 \%$ found that pristine nature must be saved even if it is not in the interest of humankind. Analogous acknowledgements of the intrinsic value of nature come from $79 \%$ of a general public sample $(n=978)$ in Sweden (Widegren 1998), and from approximately $80 \%$ of a sample of 71 college students in the US (Thompson and Barton 1994). In the Netherlands (Buijs and Volker 1997) 92\% of the respondents $(n=1999)$ agreed with the statement "nature is important for itself, independent of its functions for mankind".

3) Their earlier work (Eckberg and Blocker 1989) however, included a steward-like item in 
ship among religious respondents has been done by Schultz, Zelezny and Dalrymple (2000) who used the revised NEP-scale in 14 different countries. Unfortunately, their one-dimensional analysis of the NEP-scale does not give further insight in the different attitudes towards nature. Their study was, together with the international study of Hayes and Marangudakis (2000) and the German study of Kalbheim (2000), one of the first surveys that expanded the scope beyond the borders of the United States. Kalbheim (2000) indicated that church members adhere more to a moderate anthropocentric relationship with nature. In his study, the nonChristians were more likely to adhere to the idea of "inverted hierarchy", that sees humans as insignificant and small in comparison to nature.

The results of most studies show that the link between adherence to Christianity and environmental concern is rather weak or non- existent. Only a few significant correlations were found, for instance between belief in God and less support for environmental spending (Greeley 1993) and between belief in the Bible as the literal word of God and low levels of environmental concern (Eckberg and Blocker 1989).

This study explores how humans espousing various worldviews (secular, Christian, Buddhist, Muslim, and Native American) regard nature. Our earlier study (van den Born et al. 2001; de Groot and van den Born 2003) has shown that people, in general, no longer adhere to the viewpoint that humans have the power or right to "lord over" nature. In this study we continue to examine evidence, as provided by a variety of respondents, that attitudes toward nature are tending toward models that value stewardship, partnership, and participation.

In contrast to most previous research, this study mainly consists of in depth interviews carried out among citizens of Victoria, British Columbia. At the same time, a small questionnaire was conducted based upon the $\mathrm{HaN}$-scale. Canada makes an interesting setting for this study due to the presence of immigrants from various cultural backgrounds. This enables us to compare and contrast the basic attitudes towards nature among different religious groups in the same environment. The Canadian setting is not only suitable for studying Christian and secular attitudes to nature, but also Muslim, Buddhist and Native North American views. ${ }^{4}$

their questionnaire ("natural resources must be preserved for the future, even if people must do without"), but this goes unacknowledged in their analysis.

4) It can be stated that the inclusion of Chinese Buddhists, Gujarati Muslims and Native 
Victoria is the location of this study due to the presence of the Centre for Religion and Society there. Victoria is on the most southern point of Vancouver Island and surrounded by the Pacific Ocean. This city of approximately $300,000^{5}$ citizens still retains something of the old English colonial style with its many parks and gardens. The moderate climate permits dense deciduous and pine rainforests to flourish and attracts many elderly who have retired after spending many years in harsher climates in other parts of the country. At the same time, the university attracts many young people which makes Victoria known as the "city of newly wed and nearly dead". The parks and gardens, grand nature on the West-coast and the specific demography make Victoria a very green city. It may be assumed that on average, the respondents of this study have more 'nature-friendly' images on the human/nature relationship than most Canadians have.

With Geertz (1966), we interpret religion as one perspective among many others that together constitute culture. The religious perspective differs from the other cultural perspectives in that it moves beyond the realities of everyday life and it accepts a wider, metaphysical reality. This distinction between religion and other cultural perspectives will serve as a starting point for our study. Notably the interviews will focus on "metaphysical" issues. At the same time, religion and other perspectives influence each other; we cannot treat them as independent factors.

We start with a concise overview on human/nature relationships as described in philosophical and theologian literature. Subsequently, the methods and results of the interviews and the survey are presented, followed by the discussion.

\section{Philosophical Images of the Human/Nature Relationship}

Passmore (1974) and Barbour (1980) were among the first who made classifications of human/nature relationships. Passmore only distinguished three (anthropocentric) attitudes: Despot, Co-operation with nature, and

Americans makes this study non-Western which makes a further investigation of cultural anthropological research appropriate. Yet, we decide not to elaborate on this matter since anthropological studies mainly focus on the function and meaning of cultures (informants) and not so much on the perceptions of individuals (respondents). Moreover, the respondents can be expected to have adapted western values since they are born in Canada or have lived there for at least one decennium.

5) http://www.statcan.ca. 
Stewardship. Barbour also describes an ecocentric image, "Unity with nature". Apart from Rodman (1983), mainly Dutch philosophers and scientists further developed classifications of human/nature relationships (Zweers1989a, 1995; de Vries 1989; de Groot 1992; Kockelkoren 1993). In this study we used the basic classification of Kockelkoren, roughly consisting of Master, Steward, Partner and Participant. ${ }^{6}$

- In the image of the Master, humans stand above nature and may do with it whatever they want, not bothered by moral restraints or knowledge about nature's fragility. The master trusts economic growth and technology to solve possible environmental problems.

- The Steward stands above nature but above humans is God. Nature is a gift of God to humans and we have the responsibility to care for nature. In the secular version of Stewardship this responsibility is towards future generations rather than to God. We have this responsibility towards God (or in the secular variant towards future generations).

- The Partner stands side by side with Nature. Nature has its own status, not under humans but rather beside them. Nature unfolds in its own independent value. Humans and nature work together in a dynamic process of interaction and mutual development.

- The Participant is part of nature, not just biologically, but with a sense of (spiritual) belonging. Being part of nature is important for the identity of the Participant. Humans are not inferior to nature, but it belongs to the human possibilities to participate in nature like this.

\section{Religious Images of the Human/Nature Relationship}

In this section we focus on basic attitudes towards nature according to the religious traditions, Christianity, Islam, Buddhism and the tradition of North Native people. Note that descriptions as given below are merely general statements based upon theological literature and therefore might deviate from the very diverse interpretations of individual believers within each religion.

Christianity regards nature as a gift from God to humans. In this theocentric cosmology humans are considered spiritual beings and their place

\footnotetext{
6) See for a more detailed overview van den Born (2006) and Master thesis of de Groot (2003).
} 
is under God and the angels but above the non-spiritual nature. This leads to a dualism wherein man as a spiritual being is not part of nature but stands above it. Yet, he does not own nature, he is God's servant who has to take care for nature in His name. According to Kinsley (1995), some critics regard Christianity as the cause of the ecological crisis, because it spreads ideas of human's domination over creation, the elevation of spiritual beings and the desacralisation of nature. Although most of these critiques have counterarguments based upon the bible (Kinsley 1995), these despotic ideas can easily be found in the thoughts of the reformers.

Since Protestants are selected as the Christian subgroup in the empirical study and due to the large amount of literature on Protestantism some elaboration on the vision of nature of the reformers will be given here. According to Luther and Calvin nature is only interesting in terms of its relevance to humans. Nature is "standing under the left hand of God, the wrathful, the alien hand of God" (Weber 1958). Nature cannot save our soul because it participated with humans in the fall and is dragged down into a corrupt state (Weber 1958). Nature is therefore empty of God's presence, it is only a background of something much more important, the salvation of the human soul through Christ. Only the elect are able to read the revelation of God in nature, or in the words of Calvin, only then have we "the natural ability to mount up unto the pure and clear knowledge of God." Until that time humans emulate God and are a governor of nature, direct it and control it, remoulding it to God's glory (Keller 2000).

In Islam the idea of nature as a gift from God to humans also plays a prominent role. Unlike the bible, the Qu'ran is very precise about nature; it is "a manifestation of God's almighty power" (20:5) "Withersoever you turn there is the Face of God" (11:115), because everything God creates reflects this holiness. Since nature is a means through which God communicates with humanity, it is seen as the second Qu'ran. The cosmic Qu'ran complements the written one and both tell about God's revelation (Rockefeller and Elder 1992). Nature is regulated by natural laws directed by God's amr (command). All beings receive a unique command of God and make this command their telos or goal (Nomanul Haq 2001).

Human beings are also fully subject to the laws of nature and their $\mathrm{amr}$ is to be stewards, or God's vice-regent (al-khalifah) on earth. They do not posses nature nor should they use nature for their selfish use. They are servants who have to obey God and respect His creation (Ammar 1995). 
The ability of humans to distinguish good from evil and assert their role as vice-regents of God does not make humans stand above the plants and animals, because they all come from the same life source (Nomanul Haq 2001). "God created every animal out of water: of them there are some that creep on their bellies, others that walk on two legs and others on four" (24:25). While Christianity distinguishes spiritual beings-God, angels and humans - from the non-spiritual nature, Islam opposes a sacred God to the whole of His non-sacred creation. "None of the created are sacred except in their relation to God and in fulfilling the purpose of God's creation" (Ammar 2001).

In Buddhism the world is seen as a holistic interconnected cosmic unity in which humans are just one part among other creatures. There is no separation between humans, as spiritual beings, and plants and animals, ${ }^{7}$ since all sentient beings are composed of a spiritual and a non-spiritual element. This becomes even clearer in the Buddhist teachings of rebirth and karma. The system of rebirth makes clear that all sentient beings are interlinked and equitable, not only because they are all made out of spiritual and non-spiritual components but also because they can actually become another sentient being in another life (Gross 1995; Swearer 2001). In this web of interconnectedness wherein all causes have an effect, every entity can identify itself on two levels; the individual and the whole. On the individual level, the value and uniqueness of every individual entity is acknowledged. Every entity is in an ever-changing process due to its relations with other (changing) entities. On the level of the whole the entity merges into "the entire field of interbeing", with the whole field of interrelationships. By combining the attention for the individual life forms with the attention for the whole cosmos, Buddhism prevents a domination of the individual over the whole (anthropocentrism), or vice versa like in holism (Barnhill 2001).

Since human morality has a direct effect upon natural processes, humans should renounce greed. Driven by greed, we deny our fundamental place in nature; our interconnectedness with all the other entities in the web of being. It will only "turn us into heedless emotional turmoil” (Gross 2000).

7) In contrary to Chinese Buddhism some Japanese teachings also perceive non-living entities like stones and water as spiritual beings. 
Suffering is seen as an inextricable part of life that is partly caused by human ignorance and unnecessary violence. Therefore humans are expected to act in ways that minimize the amount of suffering inflicted on all other sentient beings (Kinsley 1995).

The religion of North American First Nations resembles those from the East in their acknowledgement of a holistic interconnected cosmos and respect for all creatures. In contrast to (Chinese) Buddhism, Native traditions consider all natural creatures and elements to be spiritual, including all elements. Moreover, all things are related as members of one universal family, born from one father, the Sky and one mother, the Earth herself. "All of nature is in us, all of us is in nature." ${ }^{8}$ The kinship relation with the local land and all the creatures living on it is especially strong (Grim 2001). Very different from the absence of a God in Buddhism, Native traditions consider all of creation to be sacred or divine. "We should know that He is within all things: the trees, the grasses (...) and even more important we should understand that He is also above all these things and peoples." ${ }^{\prime \prime}$ The Creator not only created all things but also has a continuing association in and through all of creation, since His presence is within His work (Turner and Atleo 1998). Humbleness in relation to the Creator's gift is manifested in rituals like offerings, fasting, cleansing and prayers according to a traditional protocol. Before taking a life, permission has to be asked from the Great Spirit and all parts of the creatures that are killed have to be used. It is disrespectful to waste food, play with it or refuse it when it is offered. In order to keep the cycle of life intact, the bones have to be given back to nature to give the creature the possibility to gather himself and return to the earth again (Sewid-Smith 1995).

\section{Methods}

We used a mixed method of in depth interviews and a small survey. The 27 semi-structured interviews were held among citizens with various religious backgrounds living in Victoria, BC. The first author carried out the interviews face-to-face, which took between 75 and 90 minutes. Several criteria

8) Pete Catches, Lakota elder, quoted in Lame Deer and Erdoes (1972).

9) Frank Black Elk, Oglala-Sioux, quoted in Brown (1953). 
were formulated for the selection of the respondents. First, they should be lay people. This meant the exclusion of academics in this field, religious leaders, and environmentalists. Second, we chose four religious groups that diverge greatly; two Western religions (Christianity and Islam) and two "Eastern" religions (Buddhism and Native traditions). ${ }^{10}$ We then narrowed each religion in order to get more homogenous research groups. Due to their accessibility, we chose to select members of the United Church of Canada, ${ }^{11}$ the Ismaili community ${ }^{12}$ and Chinese Buddhists. Another reason for the selection of Chinese Buddhists is that many are raised in the tradition, whereas many Tibetan Buddhists in Canada converted to Buddhism later in life.

Since the Native Americans lack a traditional religious institution, the Victoria Native Friendship Centre ${ }^{13}$ offered assistance with the selection of Native respondents. These respondents had residence of Victoria in common, but belonged to different tribes. Nevertheless the cultural differences were small since all respondents had their roots in the south of the Canadian West coast. Finally, we added a fifth research group that consisted of citizens who defined themselves as secular. All religious groups were equally represented among the respondents resulting in five members of the Church of Canada, five Ismaili Muslims, six Chinese Buddhists, five Native Americans and six secular respondents. Within each religious subgroup we attempted to equally represent sex, different educational levels and ages.

As a result of the selection of denominations within four religions it is not possible to give results on the level of for instance Buddhism or Islam

10) These religions were chosen based upon the amount of literature on the human/nature relationship.

11) The United Church of Canada is a configuration of the Canadian Presbyterian Church, Methodist Church, Congregational Union and the General Council of Union Churches (http://www.united-church.ca/ucc/history.htm).

12) Ismailis represent the second largest shi'i Muslim community after the Twelver Shia. The Ismailis and the Twelvers parted ways over the succesion to the great, great grandson of Ali and Fatima, Imam Jafar as-Sadiq, in 765. While the Twelver Shia gave their allegiance to the Imam's youngest son, the Ismailis transfer their allegiance to his eldest son Ismail (www.akdn.org/imamat.html).

13) The Victoria Native Friendship Centre mandate is to meet the needs of Native people in the Greater Victoria and by providing them with services and information designed to enhance traditional values and cultures of the Native Peoples (http://www.vnfc.ca/ home.html). 
as a whole. The small number of respondents per religious group also makes a generalisation impossible. Nevertheless, this study is rich in its description of a wide variety of human/nature relationships among both eastern and western religions. It also gives more insight in the way in which respondents link their religion to their relationship with nature.

The director of the Centre for Studies in Religion and Society was the most suitable person to find a contact person for every religious group, due to his contacts in the field. Each contact person asked one or more members of their religious institution whether they were interested in an interview about nature. We then telephoned the members to give them more information about the study and to invite them for an interview. More respondents were found via snowball sampling.

The interview consisted of two parts. The first part dealt primarily with the respondent's visions of nature. The interviewer showed ten photographs of the coastline of Vancouver Island and asked the respondents to select the photos which they would call "nature". The respondents then were asked to sort the photos from the most natural to the least natural. Further probing revealed their reasons for calling one picture more natural than the other. Subsequently the interviewer asked questions on the naturalness of humans and on the spirituality and sacredness of nature. The photographs presented the coastline with varying degrees of human activities and artifacts. All photos were taken with a standard lens in order to make the photos in accordance with the actual scale relationships that are found in the direct perception of the landscape (Coeterier 1983). Eight photographs of Victoria's coastline were taken during the same afternoon, so that the light, the season and the weather circumstances were equal in each picture. In a study of Brown and Daniel (1987) respondents reacted more positively to photos that are taken in a season yet to come than on pictures taken in the previous season. Therefore the pictures were taken in the autumn, the same season as when the interviews took place.

The second part of the interview mainly consisted of the ethical question; "How should we treat nature?" Two test interviews made it clear that this question was too broad for respondents to give an in depth answer. We decided to retain the question about the 'treatment of nature' so as to evoke an initial "blank" answer. The interviewer then explained the four attitudes towards nature; Master, Steward, Partner and Participant. Subsequently the interviewer asked the respondents for their opinion about attitudes as a whole and about the ideas that underlie the attitudes. Since 
social desirability is a difficult problem to tackle when dealing with this issue, we tried to overcome this by probing on every answer to reveal the respondent's deeper thoughts. The interviews were recorded on tape, transcribed verbatim and entered into Kwalitan, a computer program designed to deal with unstructured texts.

These interviews were supported by a first attempt to use the HaN-scale beyond Dutch borders. The aim of this survey was to reveal if the respondents distinguished the Master, Steward, Partner and Participant image. In addition to the 14 items of the HaN-scale (van den Born 2006), we developed 10 statements in order to adapt the scale to the (coastal) living environment of the respondents and to raise the validity of the survey. In line with our previous studies, questions were included to measure background variables like age, educational level and religious affiliation.

In contrast to the stratified sample of the interviews, we decided to take a random sample for the survey, as to make generalisation to the whole population of Victoria possible. The questionnaire was send to 300 randomly selected addresses from the yellow pages. Unfortunately, only 53 completed questionnaires were returned, which was partly due to the lack of a reminder and to the large number of out of date addresses which resulted in 32 returned envelopes. Almost $60 \%$ of the questionnaires returned, were completed by men, whereas according to Canadian Statistics, ${ }^{14}$ the population of Victoria consists of an equal male/female split. The age and the religious backgrounds of the respondents are similar in proportion to the population of Victoria and British Columbia respectively, ${ }^{15}$ which resulted in only one respondent with an affiliation for an Eastern religion, 19 with a Western religion and 30 non-religious respondents. Due to the low response, the survey can only give some first impressions against the background of the interviews that gave a deeper argumentation behind the images.

\section{Results}

This section will describe the results of the interviews followed by some impressions of the survey. For convenience of the reader we decided to call

14) http://www.statcan.ca/english/Pgdb/popula.htm\#pop.

15) http://www12.statcan.ca/english/profil01/PlaceSearchForm1.cfm.

http://www.statcan.ca/english/Pgdb/demo30_96c.htm. 
the respondents by the name of their world religion. We do not intend to make any generalisation what so ever.

\section{Interviews}

\section{Images of Nature}

The ten photos were used to get insight in the respondents' image of nature. From these, the respondents could select the photos which they regarded as depicting nature. The majority of respondents, from various religious backgrounds, selected a number of photos, while the others decided to select all photos. The majority explained that they selected only a number of photos because some showed too much human interference to call them nature, such as man- made structures. Especially photos of a high-rise building and a harbour were often rejected. The minority selected all the photos because for them, the presence of natural elements (the sky and the sea), or living entities (humans and animals) or greenery (the grass and the trees) on every picture was decisive:

I just think even though some of them have buildings and manmade structures on them, nature is so very much part of the landscape. And you know animals living under water and there is rocks and the clouds (...) so even though we have built things in the natural landscape, it is still nature.

Thus, after some probing all respondents regard man-made things as unnatural. Yet, for some respondents this is decisive to reject the more cultivated photos while for others this is not.

\section{Humans as Part of Nature}

The selection of the photos made clear that the respondents consider human interference as unnatural, but what about humans themselves, are they part of nature? All except one respondent concluded sooner or later that humans are part of nature. This exception was a secular man who explained that humans are above nature because we are on one of the top layers of the food chain. "We eat the salmon. That to me seems probably... if you want to admit it or not, it is an act of a higher creature feeling that it has the right to eat the salmon."

The rest of the respondents gave various reasons why humans are part of nature. Most mentioned was our dependence on natural resources like 
water and oxygen. Others called humans part of nature because we form a part in the "chain of being". "We are made up out of all the elements that are found in nature." Some religious respondents regarded humans as nature because its creation needs the involvement of a "higher power". In the words of a Muslim woman: "Humans are a creation of God, they are a natural being." Two Buddhists clarify that it took the bringing together of many causes to create both nature and humans: "The consequence of so many things together so that we have human beings (...). The ground and the mountain and the trees... There are many causes to make the ground there, the water there and the trees growing."

Although a large majority concluded that humans are part of nature, many of the later responses on this subject showed their doubts about the naturalness of humans. First, some respondents got confused by the human ability to think. "We have the brains," "we can use our wisdom" and "are self-conscious." According to some this makes us different from the rest of nature: "Obviously we are in position to change things more than every other species, so we are different, we are part of it but we have more responsibility, because of our brain." Only a few respondents of those who earlier called humans part of nature put the rational capacities of humans above the abilities of the rest of nature: "So I think at a certain point I think human is above nature."

Second, many respondents let the naturalness of humans depend on their behaviour. If humans "don't pollute", "treat it properly" and "don't make it unbalanced", then they are nature or more natural. "Humans can be part of nature. If we consider ourselves one with the earth if we respect it well enough, then I consider us part of nature." The respondents often give illustrations of more natural people like tribes in the Amazon or the Native Americans in Canada. At this point the interviewer confronted these respondents with the implication of their thoughts. Is one person more part of nature than the other, based upon their actions? Yet, all these respondents disagreed; "You can't say that some people are a part of nature and some aren't. (...) We are all people and we all do something wrong."

A third doubt on the naturalness of humans became clear when half of the respondents talked about a fundamental process of disconnection between humans and nature. Especially for the Native respondents this is an important issue: 
Sometimes, you don't think about how we are connected, we become removed from it, we don't have to think about it, we go to the grocery store and buy our food and we don't see the bugs and animals that had a hard time because of what we are doing. We are not doing it ourselves; somebody else does it for us.

Many respondents add that this alienation from nature has emerged over time. All Natives, many Buddhists, and some Muslims mentioned that humans could see God or spirits in nature as long as they have the right eyes. "Wherever you see, the God is everywhere, if you know how to see." They elaborated on the topic by saying that we forgot how to see. We got further alienated from the original spirit and spiritual contact with nature due to the development of the human intellect. The Buddhists primarily emphasised the lost connection with our own original spirit. The Natives stressed the lost connection with the spirits in nature:

To us we are told to listen to the water, the fire and we believe that trees can give us messages and that one time a long time ago the animals could all speak to us and we would be spiritually healthy enough to understand. So we are not as healthy as we used to be a long time ago.

Finally, many respondents doubted the naturalness of humans when talking about human creations. During the selection of the photos many respondents described nature as everything that was not made by humans. In doing so they tended to include humans but to exclude their artefacts. This raises the question whether these respondents regard humans as part of nature in all respects. In the words of one of the respondents who did not regard humans as part of nature; "Those who say that humans are part of nature have a sticky question to answer whether the artefacts made by human beings are also part of nature."

These points illustrate how the confusion on the naturalness of humans made the respondents swing between two different and even mutually exclusive images of nature throughout the interview. The first image of nature includes humans and under some circumstances man-made structures. The respondents sometimes explicitly referred to this image in terms of "half fully nature", "physical nature" or "partially nature." The other image of nature the respondents used, is a nature without humans. This 
nature was there before humans came, it is "not encroached on" and was often called "pure nature", "real nature" or "spiritual nature".

\section{Is Nature Sacred?}

When asked whether the respondents believed nature to be spiritual or sacred, a strong connection with the respondents' religious background appeared. A large majority of the Christians and Muslims explained that God is present in nature because it is a gift of God. "God is in the ocean. Wherever you see, the God is everywhere, if you know how to see." This seems contradictive to the Protestant and Muslim teachings, which reject the actual presence of God in nature. Yet, in their answers, the respondents stress that God's presence in nature is solely acknowledged because nature is His creation. To them nature is a medium rather than home.

None of the Buddhist respondents believed that nature is a gift from the Creator. Some explained that they do not believe in a God who created nature: "we say it is just there because all the factors come together". Other Buddhists stressed that the existence of a God above humans is not in line with their conviction that all of nature is on an equal footing. Nevertheless, all were attracted to the idea because nature feels like a gift, due to its splendour and richness. Some Buddhists liked the idea because "it disciplines people”.

Most important in the visions of the Buddhists was the spirituality of nature. "The original spirit is in all things (...) every animal, every plant." Yet, some Buddhists thought the spirit was only in animals and humans, not in plants and trees. All Buddhists were convinced that the elements do not posses a spirit. "Because water is a material object, and it cannot change its karma and its life and I won't think of it as even having a life."

The Native respondents believe that all creatures and elements have a spirit that reincarnates after their death: "Our ancestors can be the tree, or in the water, or go on top of a mountain and be up near the clouds. They are everywhere." Moreover, they all thought nature to be the same as God. "Mother earth is the Goddess, (...) the creator is not really above us, we are just all One."

In total, three secular male respondents perceived nature as pure matter, without having a soul or a spirit. The three secular women, on the other hand, believed that nature was spiritual. They thought that the beauty of 
nature was convincing enough to know that there is something out there. What this something is, was not clear to the respondents but the acknowledgement that nature is more than pure matter was an important reason for them to treat it with more respect.

\section{Images of Relationship}

During the second part of the interview the respondents could give their opinion on the Master, Steward, Partner and Participant image. First the interviewer gave the respondents a broad and explorative question on how we should treat nature. Many respondents then named general terms among which "preserve", "harmony" and "respect" were most popular. It seemed difficult for the respondents to describe what these words exactly signify. For instance, out of the 19 respondents that named respect, only 4 were able to describe it in other words; "not very indulging", "nothing should be wasted", "accept the fact that we are smaller than nature and in a way less significant" and "not trying to change". The rest of the respondents elaborated on the disrespect of our current treatment of nature. "We lose respect for nature. We tend to use it as if we own it and forget that the changes we are making to it are destroying and it cannot always rejuvenate itself."

\section{Mastership}

All respondents responded negatively on the master image, using words like "arrogant", "old-fashioned"," destructive" and "immoral". Almost half of the respondents compared the Master of nature with mastery among humans; the domination of the weakest, discrimination against women and blacks, and the unequal distribution of food in the world. Despite this negative reaction, many respondents are convinced that "there are still many people who think that way". Many respondents point out that since we are nature ourselves, in the end the Master will destroy himself. "If we damage something else it damages ourselves as well."

All respondents rejected the hierarchical relation between humans and nature. Regardless of what image we discussed, all were convinced that humans should be a part of nature. Only one respondent considered humans to be above nature because we are on one of the top layers of the food chain.

Although none of the respondents completely shared the technological optimism of the Master, all of them thought that technology could help 
solve environmental problems. One exception is a Native woman who rejected the use of technology all together.

We don't need to make big machines. Like machines that can save a tree. I don't think that a tree wants to be saved if it is that tree's time to fall down and turn into compost, and turn into dust. We want that, we need that good soil to grow our food.

\section{Steward}

In accordance with the theoretical background, all Christian and Muslim respondents were enthusiastic about the idea of Stewardship and they thought other members of their religious community would prefer this image as well. They especially liked the idea that humans have responsibility for nature, because this would oblige people to solve the environmental crisis. Yet, like almost all respondents, they stressed once again that humans are part of nature. The secular respondents differed from the Christians and Muslims in their preference to a Steward with responsibility towards future generations instead of God. Most Buddhists thought that "nature is a gift of God" was a beautiful idea, but they did not believe it was true.

Finally, the Natives rejected all elements of the Steward. Above all, they disagreed with the separation between God, humans and nature. "I think that we are just all one, we are all connected." Secondly, three out of five Natives questioned the need to take care of nature, because nature can take care of itself. One Native respondent spoke about the Steward attitude as part of their treaty negotiation. Although this western idea does not really represent the attitude of most Natives, the word Steward was used to explain to the colonists that the Natives did not want to exploit nature. "We had to try to use some words to say that we were there looking out for nature."

\section{Partner}

Only a few respondents directly agreed with the Partner. "When you see some beautiful Indian art work and carving (...) I think it is nicer to see humans working well with nature like that than having nature untouched." Most of the respondents disliked the Partner because it stresses the independent value and own identity of both nature and humans. These issues obviously appealed less than the unity between humans and nature. Moreover, many respondents disagreed with the equality of humans and 
nature. Nature is vulnerable and cannot do anything else but to endure the human impact.

The reciprocity between the Partner and nature forms another problem. Is it possible for humans to communicate with nature or to fulfil its goals? Among the collected data three different opinions on this topic can be discovered. First, three secular male respondents perceived nature as a process that will never reach a goal. The idea of having a goal is a human concept that does not apply for nature. "Nature is just an evolving process, the earth will evolve, it will happen, most of the things will happen randomly.” All Muslims, Protestants and three secular male respondents thought that nature has a goal that humans can understand to some degree by using their knowledge and brains. We know for example that nature wants to survive, that it does not want to be hurt and that it wants to be left alone. "When we see cracks in the earth we know the earth is too dry." A third group, consisting of Buddhists and Natives, thought humans can spiritually communicate with nature. According to most of the Buddhists, meditation makes us able to listen to the original spirit or Buddha nature that is present in all animals and plants. All of the Native respondents thought we can literally hear nature as long as we are willing to listen:

Nature isn't silent, it is actually screaming out to us, people are just not listening they are not there, their ears are blocked their eyes are covered, because they don't want to see, they don't want to feel anything.

\section{Participant}

All of the respondents were pleased to hear an attitude wherein humans are part of nature. Nevertheless, many had difficulties to distinguishing between a biological belonging to nature and an emotional or even spiritual connection. According to the three secular male respondents, humans do not have a spiritual connection with nature. Two of them, who were highly educated, thought that so-called spiritual experiences in nature were more of an emotional response to the beauty of nature.

It is just awareness that we are part of it and also of course when you look at the night sky, bright clear night, you are obviously attracted by it. It's an awe type of feeling you get. (...) It is an overwhelming sense, you are part of it. I would call it connectedness or emotional feeling you have with it. 
The two secular female respondents on the other hand believed that there is some kind of spirit in every living entity. "I mean I feel a God in you, in me, in all of these things. They are all existing, growing."

All of the Muslims and Christians felt a spiritual connection when they are in nature. Most of them cannot exactly describe it; "Really I don't know the answer to this, it is full of mysteries. Just like the mystery of God. Why are we here? It is a big mystery.” Two Muslims are more concrete, according to them we are able to see God in nature as long as we have the right spiritual eyes. According to the Buddhist respondents, humans can have a spiritual connection with other humans, animals and plants, due to their Buddha nature. Finally, the Natives were most clear in their description. Supported by traditional teachings and rituals, they have the possibility to connect with all of the spirits in nature.

The Native and Buddhist respondents were most fond of the Participant and they also thought other members of their community would prefer this image above the others. The Native respondents were especially enthusiastic about the Participant idea because it describes the traditional way of thinking, "the way I was taught". Many respondents did not regard the Participant to be an attitude that fits within modern society. According to some we are really too far from nature to be a Participant. Yet, all of the Natives and four out of five Buddhists did not follow this line of thought; they still consider the Participant to be a possible and desirable attitude in the present age.

At the end of the interview the respondents could chose which image of relationship they liked most. Four out of five Muslims and Christians chose the Steward as the idea that best represented their opinion under the condition that humans should be part of nature and not above. The same numbers count for the Buddhists and Natives that adhered to the Participant idea. Only the secular respondents found great difficulties in finding an attitude that corresponded with their own opinion. They all chose more than one attitude or adjusted the attitudes in order to let them fit with their ideas.

\section{Impressions from the Survey}

The factor analysis (Varimax with Kaiser Normalisation) of the HaN-scale consisted of four factors and explained $51 \%$ of the variance. ${ }^{16}$ Since the

16) The scree plot of the HaN-scale did not clearly indicate whether a distinction between 
factor loadings were rather high, we decided to take .450 as a criterion. The first factor contains 11 items and shows that the respondents distinguish a Steward, but not the theoretical one that stands above nature. Three Steward items, on conservation (.773), preservation (.885) and careful treatment of nature (0.896), have the highest factor loadings. The factor further consists of Partner and Participant items on humans as part of nature and on equality between humans and nature. Clearly the respondents here express an image of a Steward that is not above nature. The negative factor loadings on the (hierarchical) Master items (-.657, -.723, -.639) also support this.

The second factor contains five Participant items, which gives the impression that the respondents clearly distinguish this image. Factor three is a representation of an enlightened Master. This less reliable factor (Cronbach's alpha $=0.58)$ contains two Master items that express an idea to manage nature rather than to subdue it. The fourth and least reliable factor (Cronbach's alpha $=0.54)$, consists of two Steward items that represent an active involvement of humans in nature. In conclusion, the respondents did not exactly reproduce the four main groups of basic attitudes. Instead they made a clear distinction between a Steward who is a part of nature and the Participant. The distinction between the last two factors (enlightened Master and active Steward) is less convincing due to the low reliability. Therefore we did not submit these factors to further analysis.

In order to reveal the number of respondents that adhere to the Steward who is part of nature and the Participant, we calculated the mean level of agreement to the items making up the two factors, taking a mean of 1 ("agree") or higher as criterion. Note that following this method, a respondent can be ascribed to more than one image. As it turned out, $72 \%$ of the respondents adhered to the image of the Steward that is part of nature, while $15 \%$ of the respondents adhered to the image of the Participant.

The respondents were split into respondents without a religious affiliation and respondents with an affiliation to Christianity (Protestantism or Catholicism). ${ }^{17}$ The secular respondents tend to score slightly higher

three, four, five or six factors would lead to the most significant classification. Yet, only a factor analysis into three groups was possible because the extraction of all other analyses was terminated.

17) In order to split the respondents into two groups a Wicca and a Theosophist were excluded from the analysis. 
on both the Steward and the Participant image. Due to the very low probability value $(p<0.1)$ the influence of Christianity on the adherence to the Steward and Participant image cannot be proved based upon this survey. Note that in contrast to the interviews, the respondents of the survey are not necessarily practising Christians but have an affiliation with Christianity.

\section{Discussion}

Reflecting on the debate initiated by Lynn White, two hypotheses were tested: the anthropocentrism of Western culture and religion as a shaper of attitudes towards nature. To test the first hypothesis, we first empirically scrutinised the concept of nature. For all respondents the intensity of human interference in the landscape determines whether they regard it as nature. Although the interviewees regarded man-made structures as unnatural, almost all of them were convinced that humans are part of nature. The naturalness of humans was a difficult subject for the respondents. Their rational thinking seems to tell them that we are part of nature, but for most this is not confirmed by their daily experiences. They do not feel connected with nature and therefore no longer part of it. This dichotomy can also be found in the two different and even mutually exclusive visions of nature that each respondent expressed throughout the interview. One vision of nature includes humans, while the other vision is of a pure nature that is not encroached on because it excludes humans and all their interferences. That the confusion on humans as part of nature made the respondents swing between two mutually exclusive visions of nature is an important insight for future research. This phenomenon might also take place during the completion of a questionnaire on nature or the environment, sometimes resulting in illogical or even conflicting responses that might be difficult to interpret.

When looking at the human/nature relationships, we discover that the hypothesis of Lynn White on mastery over nature can be rejected, based upon our findings. Almost all respondents of the interviews reacted negatively on the Master as well as on any hierarchical relationship between humans and nature. This aversion was expressed by almost all respondents and was supported in the survey by the negative reactions to all $\mathrm{HaN}$-scale items that stated humans above nature. 
Further, both the practising religious respondents of the interviews and the randomly selected respondents of the survey were most attracted to the Stewardship image. Yet, due to their rejection of hierarchy between humans and nature, the respondents chose to adapt the traditional Steward into a Steward that is part of nature.

The Partner image did not get much support during the interviews due to its emphasis on the equality between humans and nature. The Participant was a good representation of the visions of the eastern religious respondents (Buddhist and Native). The respondents with a western religion were rather negative about the participant, mainly because they did not find it possible to feel a sense of belonging in a society that is so remote from nature.

The results show that the philosophical classification of human/nature relationships makes new empirical insights possible that were overlooked in previous studies due to their strong emphasis on anthropocentric attitudes. This is especially true for the NEP and for the quantitative studies that empirically test the White hypothesis on religion and environment. The philosophical classification presents a practicable overview of environmental values and relationships that evoke interesting thoughts among lay people on issues like the reciprocity of nature, the image of the participant and nature as a gift of God. This also appears to be the case in recent work of our research group in the Netherlands. A qualitative study carried out by van den Born (2007) shows that the Dutch are very much attracted by the image of the participant and the idea to take responsibility for nature.

The results of this study also show that the philosophical classification does not exactly coincide with the human/nature relationships expressed by lay people. The partner, an important image for philosophers, did not get much support of the respondents. Moreover, the respondents adjusted the philosophical Steward, because to them it is a self-evident idea to be part of nature and at the same time responsible for it. In philosophical literature this does not appear to be a consistent option: "how can you be part of something and yet responsible for it?" (van den Born 2007). Lay people appear to have no difficulty with this idea, however, and they would appear to be right. As an example from daily life, we may think of a class representative, who is responsible for his/her fellow students, but at the same time is not above them. Different gradations of equality are possible within the notion of being responsible for and part of a community at the 
same time. With regard to future research the classification and the $\mathrm{HaN}$ scale should be adjusted as to give respondents the possibility to choose for a Steward that is part of nature.

The interviews showed a strong relation between the religious background of the respondents and their image of nature. Especially on the question whether nature is pure matter, spiritual or sacred, the answers are very much according to the theological literature. Almost all Protestants and Muslims considered nature as a gift from God that was neither sacred nor spiritual. All Buddhists regarded nature as spiritual due to the Buddha nature, but they did not perceive nature as sacred. The Natives thought nature was both spiritual and sacred. They see the world as a person, a mother, a living entity and they use many metaphors to personify nature. This personalised worldview can be put on one extreme of a continuum with on the other extreme the materialistic worldview that was expressed by two highly educated secular men. They perceived nature as pure matter and thought it was inappropriate to think of nature in any spiritual way.

Four out of five Muslims and Protestants regarded the Steward as the most appropriate attitude towards nature, while almost all Buddhists and Native Americans preferred the Participant. Despite the adjustment of the Steward by all Christians and Muslims, none of the respondents who chose the Participant wanted to make any changes in the concept. The secular respondents all chose more than one attitude or adjusted the attitudes in order to let them fit with their ideas.

The survey findings corroborate the prevalence of the Stewardship and Participant images in Canadian society. The factor analysis showed that here too, stewardship was seen as stewardship in nature. In contrast to the interviews, the survey did not show a link between religion and human/ nature relationships. Due to the random selection of citizens, the survey included mainly respondents with a Christian or no religious affiliation. Our analysis focused only on Christianity and did not show a link between Christianity and human/nature relationships. This is in line with many previous studies as described in the introduction.

The Partner was hardly chosen as the most appropriate relationship with nature during the interviews. Nevertheless, the reactions to the notion of reciprocity suggest a relation between religion and attitudes towards nature. All Muslims, Protestants and female secular respondents thought that nature has a goal, which humans can understand if they use their 
knowledge and brains. The Buddhists and Natives thought it is possible to be aware of the goals of nature on a spiritual level, through the Buddha nature or because spirits in nature talk to us.

Despite the small number of respondents, these findings shine a new light on possibilities for future empirical research to study in depth the link between religion and human/nature relationships. Future studies that continue to include the world's religious traditions will be especially helpful in understanding the relationship between humans and the natural world we all inhabit.

In the last century, scholars such as the historian Lynn White, Jr., assumed that Christian believed that God created the world and gave human beings permission to exploit the fruits of the earth. As we move into the 21 st century, adherents of all faiths as well as secularists seem to be embracing a more relational attitude toward nature, wishing to extend care and concern to the earth as responsible stewards, and, in the case of Buddhists and Native Americans, seeking intimacy and participation in the rhythms of nature.

\section{References}

Ammar, N.H. 1995. "Islam, Population, and the Environment: A Textual and Juristic View" in H. Coward (ed.) Population, Consumption, and the Environment, Religious and Secular Responses. New York: State University of New York Press, pp. 123-136.

- 2001. "Islam and Deep Ecology" in D.L. Barnhill and S. Gottlieb (eds.) Deep Ecology and World Religion: New Essays on Sacred Ground. New York: State University of New York Press, pp. 193-211.

Barbour, Ian G. 1980. Technology, Environment, and Human Values. New York: Praeger.

Barnhill, D.L. 2001. "Relational Holism" in D.L. Barnhill and S. Gottlieb (eds.) Deep Ecology and World Religion: New Essays on Sacred Ground. New York: State University of New York Press, pp. 77-106.

Boyd, H.H. 1999. "Christianity and the Environment in the American Public". Journal for the Scientific Study of Religion 38(1): 36-44.

Brown, J.E.P. (ed.) 1953. The Sacred Pipe, Black Elk's Account of the Seven Rites of the Oglala Sioux. Oklahoma: University of Oklahoma Press.

Brown, T.C. and T.C. Daniel. 1987. "Context Effects in Perceived Environmental Quality Assessment; Scene Selection and Landscape Quality Ratings". Journal of Environmental Psychology 7: 233-250.

Buijs, A.E. and P. Filius. 1998. Natuurbeelden in de praktijk. De invloed van natuurbeelden en natuurvisies op gedrag en mening over beleid. Wageningen: DLO-Staringcentrum.

Buijs, A.E. and C.M. Volker. 1997 Publiek draagvlak voor natuur en natuurbeleid. Wageningen: DLO-Staringcentrum.

Callicot, J.B. 1983. "Traditional American Indian and Traditional Western European Attitudes towards Nature: An Overview" in R. Elliot and A. Gare (eds.) Environmental Philosophy. New York: University of Queensland Press, pp. 231-259. 
Cobb, Jr., J.B. 2001. "Protestant Theology and Deep Ecology" in D.L. Barnhill and S. Gottlieb (eds.) Deep Ecology and World Religion:New Essays on Sacred Ground. New York: State University of New York Press, pp. 213-227.

Coeterier, J.F. 1983. "A Photo Validity Test”. Journal of Environmental Psychology 3: 315-323. de Groot, M. 2003. The Sea and I; An Interdisciplinary Research on the Relation between Humans and Nature among the Population of Victoria, Canada, Nijmegen: Unpublished Master thesis Catholic University Nijmegen (ftp://ftp.sci.kun.nl/pub/ucm/Mirjam/ ScriptieMdeGroot.pdf).

de Groot, W.T. 1992. Environmental Science Theory: Concepts and Methods in a ProblemOriented, One-World Paradigm. Amsterdam: Elsevier Science Publishers.

de Groot, W.T. and R.J.G. van den Born. 2003. "Visions of Nature and Landscape Type Preferences: An Exploration in the Netherlands". Landscape and Urban Planning 63: 127-138.

de Vries, H.J.M. 1989. Sustainable Resource Use, an Inquiry into Modelling and Planning. Groningen: Groningen University Press.

Dunlap, R.E., K.D. Van Liere, A.G. Mertig and R.E. Jones 2000. "Measuring Endorsement of the New Environmental Paradigm: A Revised NEP Scale". Journal of Social Issues 56: 425-442.

Eckberg, D.L. and T.J. Blocker. 1989. "Varieties of Religious Involvement and Environmental Concerns: Testing the Lynn White Thesis". Journal for the Scientific Study of Religion 28: 509-517.

1996. "Christianity, Environmentalism, and the Theoretical Problem of Fundamentalism”. Journal for the Scientific Study of Religion 35: 343-355.

Geertz, C. 1966. "Religion as a Cultural System" in M. Banton (ed.) Anthropological Approaches to the Study of Religion. New York: Praeger, pp. 1-46.

Greeley, A. 1993. "Religion and Attitudes toward the Environment". Journal for the Scientific Study of Religion 32: 19-28.

Grendstad, G. and D. Wollebeak 1998. "Greener Still? An Empirical Examination of Eckersley's Ecocentric Approach". Environment and Behavior 30: 653-675.

Grim, J.A. 2001. "Indigenous Traditions and Deep Ecology" in D.L. Barnhill and S. Gottlieb (eds.), Deep Ecology and World Religion:New Essays on Sacred Ground. New York: State University of New York Press, pp. 35-57.

Gross, R.M. 1995. "Buddhist Resources for Issues of Population, Consumption, and the Environment" in H. Coward (ed.) Population, Consumption, and the Environment, Religious and Secular Responses. New York: State University of New York Press, pp. 155-172.

—. 2000. "Toward a Buddhist Environmental Ethic" in H. Coward and D.C. Maguire (eds.) Visions of a New Earth, Religious Perspectives on Population, Consumption, and Ecology. New York: State University of New York Press, pp. 147-160.

Guth, J.L., J.C. Green, L.A. Kellstedt and C.E. Smidt. 1995. "Faith and the Environment: Religious Beliefs and Attitudes on Environmental Policy". American Journal of Political Science 39: 364-382.

Hand, C.M. and D.K. Van Liere. 1984. "Religion, Mastery-Over-Nature, and Environmental Concern". Social Forces 63: 555-570.

Hayes, B.C. and M. Marangudakis. 2000. "Religion and Environmental Issues within Anglo-American Democracies". Review of Religious Research 42: 159-174.

Kahn, P.H. 1999. The Human Relationship with Nature: Development and Culture. Cambridge, MA: The MIT Press.

Kalbheim, B. 2000. Sinngebung der Natur und ökologisches handeln, Eine empirisch theologische Untersuchung zu Motiven umweltschützenden Handelns bei Kirchn-und Nichtkirchenmitgliedern. Nijmegen: Nijmegen University Press. 
Kaltoft, P. 1999. "Values about Nature in Organic Farming Practice and Knowledge". Sociologia Ruralis 39: 39-53.

Keller, C. 2000. "The Lost Fragrance: Protestantism and the Nature of What Matters" in H. Coward and D.C. Maguire (eds.) Visions of a New Earth, Religious Perspectives on Population, Consumption, and Ecology. New York: State University of New York Press, pp. 79-94.

Kellert, S.R. 1989. "Perception of Animals in America" in R.J. Hoage (ed.) Perceptions of Animals in American Culture. Washington, DC: Smithsonian Institution Press, pp. 5-24.

Kinsley, D. 1995. Ecology and Religion: Ecological Spirituality in Cross-Cultural Perspective. Upper Saddle River, NJ: Prentice Hall.

Kockelkoren, P.J.H. 1993. “De vernieuwing van Nederland”. Locus Seminar 4: 11-16.

Lame Deer, J.F. and R. Erdoes 1972. Lame Deer, Seeker of Visions. New York: Simon and Schuster.

Modelmog, I. 1998. "Nature' as a Promise of Happiness: Farmers' Wives in the Area of Ammerland, Germany". Sociologia Ruralis 38: 109-122.

Nevers, P., U. Gebhard and E. Billmann-Mahecha. 1997. "Patterns of Reasoning Exhibited by Children and Adolescents in Response to Moral Dilemma's Involving Plants, Animals and Ecosystems". Journal of Moral Education 26: 169-186.

Nomanul Haq, S. 2001. "Islam and Ecology: Toward Retrieval and Reconstruction". Daedalus, Journal of the American Academy of Arts and Sciences 130: 141-178.

Passmore, J. 1974. Man's Responsibility for Nature. Ecological Problems and Western Traditions. London: Duckworth.

Rockefeller, S.C. and J.C. Elder. 1992. Spirit and Nature, Why the Environment is a Religious Issue. Boston: Beacon Press.

Rodman, J. 1983. "Four Forms of Ecological Consciousness Reconsidered" in D. Scherer and T. Attig (eds.) Ethics and the Environment. Upper Saddle River: NJ: Prentice-Hall, pp. 82-92.

Schultz, P.W., L. Zelezny and N.J. Dalrymple. 2000. "A Multinational Perspective on the Relation between Judeo-Christian Religious Belief and Attitudes of Environmental Concern". Environment and Behavior 32: 576-591.

Sewid-Smith, D. 1995. "Aboriginal Spirituality, Population, and the Environment" in H. Coward (ed.) Population, Consumption, and the Environment, Religious and Secular Responses. New York: State University of New York Press, pp. 63-72.

Shaiko, R.G. 1987. "Religion, Politics, and Environmental Concern: A Powerful Mix of Passions". Social Science Quarterly 68: 244-262.

Swearer, D.K. 2001. "Principles and Poetry, Places and Stories: The Resources of Buddhist Ecology". Daedalus, Journal of the American Academy of Arts and Sciences 130: 225-242.

Thompson, S.C. and M.A. Barton. 1994. "Ecocentric and Anthropocentric Attitudes toward the Environment". Journal of Environmental Psychology 14: 149-157.

Tucker, M.E. and J.A. Grim. 2001. "Introduction: The Emerging Alliance of World Religions and Ecology". Daedalus, Journal of the American Academy of Arts and Sciences 130: $1-22$.

Turner, N. and R. Atleo. 1998. "Pacific North American First Peoples and the Environment" in H. Coward (ed.) Traditional and Modern Approaches to the Environment on the Pacific Rim, Tensions and Values. New York: State University of New York Press, pp. 105-124.

van den Berg, A.E. 1999. Individual Differences in the Aesthetic Evaluation of Natural Landscapes. Groningen: Groningen University Press. 
van den Born, R.J.G., R.H.J. Lenders, W.T. de Groot and E. Huijsman. 2001. "The New Biophilia: An Exploration of Visions of Nature in Western Countries". Environmental Conservation 28: 65-75.

van den Born, R.J.G. 2006 "Implicit Philosophy: Images of the Relationship between Humans and Nature in the Dutch Population" in R.J.G. van den Born, R.H.J. Lenders and W.T. de Groot (eds.) Visions of Nature, a Scientific Exploration of People's Implicit Philosophy. Berlin: LIT-Verlag.

- 2007. Rethinking Nature: Everyday Philosophy of Nature in the Netherlands. Nijmegen: Radboud University Nijmegen.

Weber, M. 1958. The Protestant Ethic and the Spirit of Capitalism, a Classic Study of the Fundamental Relationship between Religion and the Economic and Social Life in Modern Culture. New York: Scribner.

White, L. 1967. "The Historical Roots of Our Ecological Crisis". Science 155: 1203-1207.

Widegren, O. 1998. "The New Environmental Paradigm and Personal Norms". Environment and Behavior 30: 75-100.

Woodrum, E. and T. Hoban. 1994. "Theology and Religiosity Effects on Environmentalism". Review of Religious Research 35: 193-206.

Zweers, W. 1989. "Grondhoudingen ten opzichte van de natuur". Heidemijtijdschrift Juni:74-80.

-1 1995. Participeren aan de natuur. Utrecht: Van Arkel. 